\title{
First Demonstration of Bovine Herpesvirus 2 Infection among Cattle by Neutralization Test in Japan
}

\author{
Kunitoshi IMAI ${ }^{1)}$, Ryoko ISHIHARA ${ }^{1)}$ and Tomoko NISHIMORI ${ }^{1)}$ \\ ${ }^{1)}$ Hokkaido Research Station, National Institute of Animal Health, 4 Hitsujigaoka, Toyohira, Sapporo, Hokkaido 062-0045, Japan
}

(Received 30 July 2004/Accepted 5 November 2004)

\begin{abstract}
Seroepidemiological surveys were performed on neutralizing antibody to bovine herpesvirus 2 (BoHV-2) among cattle in Japan. A total of 1,819 sera were collected from cattle in 27 prefectures from 1997 to 1998 . Antibodies were detected in only 18 sera collected from 4 prefectures. However, the most prevalent areas of the infection were found in two islands located in the subtropical zone. Additional 353 sera were collected in three including these islands in 1999-2001. The antibody-positive rates in the farms in these islands ranged from $10 \%$ to $81.1 \%$. It was confirmed that BoHV-2 was prevalent in these areas. However, the infection seemed to be latent, because no diseases have been noticed. This is the first report showing the presence of BoHV-2 infection among cattle in Japan. KEY WORDS: bovine herpesvirus 2 , neutralizing antibody.
\end{abstract}

J. Vet. Med. Sci. 67(3): 317-320, 2005

Bovine herpesvirus 2 (BoHV-2) is a virus of the genus Simplexvirus and member of the Alphaherpesvirinae subfamily within the Herpesviridae family. The close antigenic and genetic relationship between BoHV-2 and herpes simplex virus (HSV) has been reported [14]. HSV can exist as a latent infection [18], while BoHV-2 can also caused a latent infection in cattle [10].

BoHV-2 is associated with two main clinical forms in cattle: bovine herpes mammillitis characterized by a vesicular, ulcerated or necrotic lesions of the teat and udder skin, and pseudo-lumpy skin disease (PLSD) characterized by generalized superficial skin lesions. BoHV-2 was first isolated from cases of lumpy skin disease in Africa in 1957 [1]. Subsequently, the viruses have been isolated from cases of mammillitis in several European countries, the U.S.A. and Australia [4].

Although it has not been fully elucidated how BoHV-2 is transmitted between herds, it is assumed that mechanical transmission of the virus by insect vectors such as biting flies occurs [4]. The disease may spread rapidly through a herd, but in some outbreaks the disease may be confined to newly purchased susceptible cattle or young stock [4].

Seropositive cattle with antibodies to BoHV-2 have been reported in African and European countries, the U.S.A., and Australia [3, 8, 9, 11, 12, 15].

In Japan, farmers claim that mammillitis leading to serious economic losses in dairy cattle has increased in recent years.

However, attempts to isolate BoHV-2 have failed in the cattle affected with mammillitis, although the virus is suspected to be the aetiology of the disease. In addition, a survey on antibodies against BoHV-2 has not been conducted. In this study, we describe the first detection of neutralizing

\footnotetext{
* The present address and Correspondence to: Dr. Imai, K., Research Center for Animal Hygiene and Food Safety, Obihiro University of Agriculture and Veterinary Medicine, 2-11 Inada, Obihiro, Hokkaido 080-8555, Japan.
}

antibodies to BoHV-2 from cattle in Japan.

The Minnesota strain of BoHV-2 [19] was propagated on primary fetal bovine muscle (FBM) cells was used.

Serum neutralization (SN) tests were carried out as previously described [2] except that FBM cells were used. Cattle sera were first screened at a single dilution of 1:4 in 2 wells. Antibody titers were measured in two-fold dilutions beginning with a 1:4 dilution of the serum, and endpoint titers corresponding to $50 \%$ neutralization were calculated by the Behrens-Kärber method. A total of 1,819 cattle sera (mostly dairy cattle) were collected in 27 out of the 47 prefectures through 1997 to 1998 (Table 1). In principle, more than 50 sera were randomly collected from cattle on several farms in each prefecture. From 1999 to 2001, in addition, more cattle sera were collected for further epidemiological investigation in the two prefectures (Kagoshima and Okinawa) where BoHV-2 neutralizing antibodies were detected. The numbers of sera collected are shown in Tables 2 and 3. Data were statistically analyzed using the chi-square test.

BoHV-2 antibodies were detected in only $18(0.99 \%)$ of the 1,819 cattle sera in 4 of the 27 prefectures, and the positive rate in the cattle of these four prefectures ranged from 2 to $10 \%$ (Table 1). In Aomori Prefecture, only 3 of the 10 cattle in one Japanese beef cattle farm had antibodies. The titers ranged from 1:4 to $1: 8$. There was no information regarding these cattle except that the seropositive cattle were breeders.

Other seropositive farms were found in three prefectures (Oita, Kagoshima, and Okinawa). Only one out of the 50 cattle examined in Oita Prefecture had BoHV-2 antibody with the titer of 1:45. Any other information regarding this cow was not obtained except that the cow was introduced from the U.S.A.

In Kagoshima Prefecture, only one (farm A) of the 10 farms examined in 10 different areas was seropositive (Table 1), and $4(66.7 \%)$ of the 6 cattle had BoHV-2 antibodies in farm A (Table 2). Antibody titers ranged from 
Table 1. Detection of BoHV-2-neutralizing antibodies in cattle in various parts of Japan from 1997 to 1998

\begin{tabular}{|c|c|c|c|c|}
\hline \multirow[b]{2}{*}{ District } & \multirow[b]{2}{*}{ Prefecture } & \multicolumn{2}{|c|}{ Detection of antibody to BoHV-2 } & \multirow{2}{*}{$\begin{array}{l}\text { Range of antibody titer }{ }^{\mathrm{b})} \\
(\mathrm{GM})^{\mathrm{c})}\end{array}$} \\
\hline & & Farm & Cattle $(\%)$ & \\
\hline & Hokkaido & $0 / 135^{\mathrm{a})}$ & $0 / 330$ & \\
\hline \multirow[t]{3}{*}{ Tohoku } & Aomori & $1 / 5(20)$ & $3 / 50(6)$ & $4-8(5.0)$ \\
\hline & Iwate & No data & $0 / 50$ & \\
\hline & Yamagata & No data & $0 / 50$ & \\
\hline \multirow[t]{4}{*}{ Kanto } & Chiba & $0 / 22$ & $0 / 110$ & \\
\hline & Ibaraki & $0 / 9$ & $0 / 50$ & \\
\hline & Tochigi & $0 / 5$ & $0 / 50$ & \\
\hline & Gunma & $0 / 8$ & $0 / 59$ & \\
\hline \multirow[t]{3}{*}{ Chubu } & Niigata & No data & $0 / 50$ & \\
\hline & Nagano & No data & $0 / 50$ & \\
\hline & Gifu & $0 / 8$ & $0 / 50$ & \\
\hline \multirow[t]{3}{*}{ Kinki } & Mie & $0 / 5$ & $0 / 50$ & \\
\hline & Shiga & $0 / 5$ & $0 / 50$ & \\
\hline & Wakayama & $0 / 5$ & $0 / 50$ & \\
\hline \multirow[t]{3}{*}{ Chugoku } & Okayama & $0 / 11$ & $0 / 55$ & \\
\hline & Tottori & $0 / 6$ & $0 / 60$ & \\
\hline & Hiroshima & $0 / 9$ & $0 / 61$ & \\
\hline \multirow[t]{2}{*}{ Shikoku } & Ehime & No data & $0 / 77$ & \\
\hline & Kochi & No data & $0 / 64$ & \\
\hline \multirow[t]{9}{*}{ Kyushu } & Fukuoka & No data & $0 / 53$ & \\
\hline & Oita & No data & $1 / 50(2)$ & 45 \\
\hline & Saga & $0 / 25$ & $0 / 50$ & \\
\hline & Nagasaki & $0 / 8$ & $0 / 50$ & \\
\hline & Kumamoto & $0 / 13$ & $0 / 50$ & \\
\hline & Miyazaki & $0 / 8$ & $0 / 50$ & \\
\hline & Kagoshima & $1 / 10(10)$ & 4/50(8) & $5.6-22.6(11.2)$ \\
\hline & Okinawa & $6 / 15(40)$ & 10/100 (10) & $8-32(15.8)$ \\
\hline & Total & & 18/1,819(0.99) & \\
\hline
\end{tabular}

a) Number of positive /a total number examined.

b) Reciprocal serum-neutralization titer.

c) GM: geometric mean of antibody titers.

Table 2. Detection of BoHV-2-neutralizing antibodies in cattle in Tanegashima island of Kagoshima Prefecture

\begin{tabular}{cccc}
\hline Year & Farm & No. of seropositive cattle $(\%)$ & $\begin{array}{c}\text { Range of antibody titer } \\
(\mathrm{GM})^{\mathrm{d})}\end{array}$ \\
\hline 1997 & $\mathrm{~A}$ & $4 / 6(66.7)^{\mathrm{a})}$ & $5.6-22.8(15.8)$ \\
2000 & $\mathrm{~A}$ & $\left.2 / 10(20.0)^{\mathrm{A}} \mathrm{b}\right)$ & $22.6-32(26.8)$ \\
& $\mathrm{B}$ & $7 / 10(70.0)^{\mathrm{B}}$ & $4-32(7.9)$ \\
& $\mathrm{C}$ & $3 / 10(30.0)^{\mathrm{A}}$ & $4-32(8.9)$ \\
& $\mathrm{D}$ & $1 / 10(10.0)^{\mathrm{A}}$ & 32 \\
\hline
\end{tabular}

a) Number of positive / a total number examined.

b) Data followed by different superscript letters (A, B) in 2000 were significantly different $(\mathrm{P}<0.05)$.

c) Reciprocal serum-neutralization titer.

d) GM: geometric mean of antibody titers.

1:5.6 to $1: 22.6$. This farm was located in Tanegashima island $\left(30^{\circ} \mathrm{N}\right)$ belonging to this prefecture. Cattle sera were collected from four farms (B, C and D) in addition to farm A in order to obtain further information about the prevalence of BoHV-2 on this island in 2000 (Table 2). Antibodies were detected in all the farms examined, and the titers ranged from $1: 4$ to $1: 32$. The positive rate in farm $\mathrm{A}$ was $20 \%$ in 2,000 ; however, it was not statistically low com- pared with the previous positive rate $(66.6 \%)$ in 1997 . As shown in Table 2 , the positive rate in farm B was significantly higher than that in the other 3 farms $(\mathrm{P}<0.05)$. However, mammillitis or PLSD was not noticed by the owners of this farm as well as by those of other farms.

The most prevalent area of BoHV-2 infection was found in Okinawa Prefecture which consists of many islands, and is located in the end of the south-western part of Japan. Six 
Table 3. Detection of BoHV-2-neutralizing antibodies in Okinawa Prefecture from 1997 to 2001

\begin{tabular}{|c|c|c|c|c|}
\hline \multirow{2}{*}{$\begin{array}{r}\text { Area } \\
\text { Island }\end{array}$} & \multirow[b]{2}{*}{ Year } & \multicolumn{2}{|c|}{ Detection of BoHV-2-antibodies ${ }^{a}$} & \multirow{2}{*}{$\begin{array}{l}\text { Range of antibody titer }{ }^{\mathrm{b})} \\
\qquad(\mathrm{GM})^{\mathrm{c})}\end{array}$} \\
\hline & & Farm (\%) & Cattle (\%) & \\
\hline Okinawa & 1999-2001 & $8 / 22(36.3)$ & $31 / 260(11.9)$ & $4-90.5(8.8)$ \\
\hline Ishigaki & 2001 & $1 / 1(100.0)$ & $43 / 53(81.1)$ & $4-256(16.6)$ \\
\hline \multicolumn{2}{|c|}{ Total } & $9 / 23(39.1)$ & $74 / 313(23.6)$ & \\
\hline
\end{tabular}

a) Number of positive / a total number examined.

b) Reciprocal serum-neutralization titer.

c) GM: geometric mean of antibody titers.

Table 4. Antibody incidence among cattle with different calving histories

\begin{tabular}{cccccccc}
\hline & \multicolumn{7}{c}{ Numbers of positive cattle sera } \\
\cline { 2 - 8 } $\begin{array}{c}\text { Antibody } \\
\text { titer }\end{array}$ & Heifers & $\begin{array}{c}\text { First } \\
\text { calvers }\end{array}$ & $\begin{array}{l}\text { Second } \\
\text { calvers }\end{array}$ & $\begin{array}{c}\text { Third } \\
\text { calvers }\end{array}$ & $\begin{array}{c}\text { Fourth } \\
\text { calvers }\end{array}$ & $\begin{array}{c}\text { Fifth } \\
\text { calvers }\end{array}$ & $\begin{array}{c}\text { >sixth } \\
\text { calvers }\end{array}$ \\
\hline$<4$ & 62 & 85 & 45 & 51 & 18 & 15 & 6 \\
$4-64$ & 7 & 7 & 16 & 17 & 12 & 5 & 5 \\
$>64$ & 1 & 0 & 0 & 2 & 1 & 1 & 0 \\
\hline Positive & $8 / 70^{\mathrm{a})}$ & $7 / 92$ & $16 / 61$ & $19 / 70$ & $13 / 31$ & $6 / 21$ & $5 / 11$ \\
rate $(\%)$ & $(11.4)^{\mathrm{Ab})}$ & $(7.6)^{\mathrm{A}}$ & $(26.2)^{\mathrm{B}}$ & $(27.1)^{\mathrm{B}}$ & $(41.9)^{\mathrm{B}}$ & $(28.6)^{\mathrm{B}}$ & $(45.5)^{\mathrm{B}}$ \\
\hline
\end{tabular}

a) Number of positive /a total number of sera examined.

b) Data followed by different superscript letters $(\mathrm{A}, \mathrm{B})$ were significantly different $(\mathrm{P}<0.05)$.

(40\%) of the 15 farms examined in Okinawa's main island $\left(26^{\circ} \mathrm{N}\right)$ were found to be seropositive in 1997-1998 (Table 1 ), and the antibody incidence in these seropositive farms ranged from 14 to $50 \%$. Antibody titers were in the range of 1:8 to 1:32. Neither Mammillitis nor PLSD was noticed on these farms.

From 1999 through 2001, a total of 313 sera were collected from 22 farms in Okinawa's main and from one farm in Ishigaki islands $\left(24^{\circ} \mathrm{N}\right)$ in order to obtain further epidemiological information regarding the prevalence of BoHV-2 in this prefecture, respectively. Seropositive cattle were found in $9(39.1 \%)$ of 23 farms (Table 3 ), and the incidence of antibody in the seropositive farms ranged from 5.0 to $81.1 \%$. The titers were in the range of $1: 4$ to $1: 256$. Mammillitis or PLSD was not a problem in the seropositive farms. Two farms in Okinawa's main island and Ishigaki island had a high incidence of antibody, $8(80.0 \%)$ of 10 cattle with the antibody titer range of $1: 4$ to $1: 22$, and 43 $(81.1 \%)$ of 53 cattle with an antibody titer range of $1: 4$ to $1: 256$, respectively.

On Okinawa's main island, a total of 37 farms were examined from 1997 through 2001. Seropositive farms were scattered throughout this island. Even in the same areas, seropositive farms showed a sporadic distribution.

Antibody incidence among cattle with different calving histories was compared. The positive rate in heifers and first calvers were significantly lower than those in other older calvers $(\mathrm{P}<0.05$, Table 4$)$.

From breeding records obtained in 28 (303 cattle) of 38 farms examined from 1997 to 2001 in Okinawa Prefecture, 222 cattle had been introduced from the outside of this pre- fecture; all were Hokkaido Prefecture located in the northern part of Japan except one cattle from the U.S.A., and the remainder ( 81 cattle) had been bred in their own farms. The antibody incidence in each group was $6.3 \%$ of 222 cattle, and $71.6 \%$ of 81 cattle, respectively. The antibody incidence in the former group was significantly lower than that in the latter $(\mathrm{P}<0.001)$.

Throughout the present survey, a total of $95.3 \%$ of 105 positive sera had the antibody titers ranging from 1:4 to $1: 64$.

This study first showed the presence of BoHV-2 infected cattle in Japan. However, the antibody incidence was very low throughout the country. The distribution of seropositive farms was regionally biased. They were detectable only in four prefectures. However, the area of BoHV-2 infection having the highest prevalence was found to be Tanegashima island $\left(30^{\circ} \mathrm{N}\right)$ in Kagoshima Prefecture, and Okinawa's main island $\left(26^{\circ} \mathrm{N}\right)$ and Ishigaki island $\left(24^{\circ} \mathrm{N}\right)$ in Okinawa Prefecture.

Although the transmission mode of BoHV-2 under natural conditions has not been fully elucidated, it is considered that biting flies are important in the mechanical transmission of the virus [4]. Weiss [17] isolated BoHV-2 from Biomyia fasciata caught on cattle with PLSD in Africa. PLSD has the highest incidence in the summer months and occurs most commonly in moist, low-lying area. Mammillitis outbreaks in the UK and Australia had also a seasonal incidence $[5,16]$. In New York State of the U.S.A., the virus spread throughout the cattle herd with its peak transmission occurring during summer and autumn [7]. Stomoxys calcitrans and Rhipicephalus appendiculatus were also suspected as 
possible vectors of BoHV-2 [6, 13]. However, transmission attempts of infection by these vectors have failed. In Australia, the much higher incidence of the antibody was reported in cattle sera collected in the far north side of $20^{\circ} \mathrm{S}$, suspecting the involvement of biting flies [15]. In this study, the islands where BoHV-2 infection was prevalent are located in the subtropical zone between $20^{\circ} \mathrm{N}$ and $30^{\circ} \mathrm{N}$, where insect-born diseases such as Akabane disease extensively occur through the year. It may be therefore possible that a certain kind of insect vector carrying BoHV-2 is present in these areas, although we have not inspected the insect population in the areas in involvement with BoHV-2 infection. However, some doubt remains regarding this hypothesis, because the distribution of seropositive farms seen in Okinawa's main island, though a small island $(1,185$ $\mathrm{km}^{2}$ ), was scattered.

BoHV-2 infections are usually subclinical $[7,15]$. Once BoHV-2 has invaded a herd, the virus may easily cause a latent infection, and the cattle are immune. Consequently, the disease in a herd may occur only in young stocks or newly purchased susceptible cattle [4]. In Okinawa Prefecture, although many cattle are introduced to farms from the outside of this prefecture, the occurrence of mammillitis or PLSD has not been noticed in the cattle introduced to farms, even in the farms with the high antibody incidence. It is unclear why the disease has not occurred so far.

BoHV-2 spread rapidly among bulls housed together and to others in a separate barn without showing any clinical signs. Probably, the latent virus occasionally reactivated was transmitted, perhaps by direct contact [7]. As shown in Table 4, the number of seropositive cattle increased with age. Martin and Scott [10] reported that cattle inoculated with BoHV-2 excreted infective virus following the administration of corticosteroid many weeks after primary exposure to the virus. Since immunity does not correlate with the presence of neutralizing antibody, it is likely that reinfections due to reactivation of the latent virus caused by immunosuppression were repeated among immune cattle in the seropositive herds. If so, it would be difficult to exclude BoHV-2 from the infected farms.

ACKNOWLEDGEMENTS. We wish to thank the members of the Livestock Hygiene Service Stations for collecting serum samples, especially, the members of Kagoshima and Okinawa Prefectures for collecting more samples. We also wish to thank Dr. T. Imada, the National Institute of Animal Health, Japan for his support in preparing the manuscript. This study was partially supported by the special fund (Jonai Project) of the National Institute of Animal Health, Japan.

\section{REFERENCES}

1. Alexander R.A., Plowright, W. and Haig, D.A. 1957. Bull. Epizoot. Dis. Afr. 5: 489-492.

2. Busbnell, S.E. and Edwards, S. 1988. J. Biol. Stand. 16: 45-53.

3. Dardiri, A.H. and Stone, S.S. 1972. Proc. Annu. Meet. U.S. Anim. Hlth. Assoc. 76:156-171.

4. Gibbs E.P.J. and Rweyemamu, M.M. 1977. Vet. Rec. 47: 411425.

5. Gibbs E.P.J., Johnson, R.H. and Osborne, A.D. 1972. Vet. Rec. 91: 395-401.

6. Gibbs, E.P.J., Johnson, R.H. and Osborne, A.D. 1973. Res. Vet. Sci. 14: 139-144.

7. Letchworth, G.J. 3rd. and Ladue, R. 1982. Cornell Vet. 72: 200-210.

8. Martin, W.B. 1990. pp. 109-116. In: Virus Infections of Ruminants (Dinter, Z. and Morein, B. eds.), Elsevier Science Publishers B.V, New York.

9. Martin, W.B. and Gwynne, M. 1968. Bull. Epizoot. Dis. Afr. 16: $217-222$.

10. Martin, W.B. and Scott, F.M. 1979. Arch. Virol. 60: 51-58.

11. Plowright, W. and Jessett, D.M. 1971. J. Hyg. 69: 209-222.

12. Rweyemamu, M.M., Johnson, R.H. and Laurillard, R.E. 1969. Bri. Vet. J. 125: 317-325.

13. Schiemann, B. and Gwamaka, B. 1972. J. Wildlife Dis. 8: 141145.

14. Sterz, H., Ludwig, H. and Rott, R. 1974. Intervirology 2: 1-13.

15. St. George, T.D. 1983. Aust. Vet. J. 60: 187-189.

16. Turner, A. J., Morgan, I. R., Sykes, W. E. and Nicholls, W. A. 1976. Aust. Vet. J. 52: 170-173.

17. Weiss, K.E. 1963. pp. 179-201. In: Emerging Diseases of Animals. FAO Agricultural Studies No.61, FAO, Rome.

18. Whitley, R.J. 2001. pp. 2461-2509. In: Field of Virology, 4th ed.(Knipe, D.M., Howley, P.M., Griffin, D.E., Martin, M.A., Lamb, R.A. and Roizman, B. eds.), Williams \& Wilkins, Philadephia.

19. Yedloutschnig, R.J., Brerese, S.S., Jr. Hess, W.R., Dardiri, A.H., Tatlor, W.D., Barnes, D.M., Page, R.W. and Ruebke, H.J. 1970. Proc. Annu. Meet. U.S. Anim. Hlth. Assoc. 74: 208212. 